\title{
Utilization of Industrial Byproducts for Enhancing the Properties of Cement Mortars at Elevated Temperatures
}

\author{
Vasiliki Pachta *(D) and Eleftherios K. Anastasiou (D) \\ Laboratory of Building Materials, School of Civil Engineering, Aristotle University of Thessaloniki, \\ 54124 Thessaloniki, Greece; elan@civil.auth.gr \\ * Correspondence: vpachta@civil.auth.gr
}

Citation: Pachta, V.; Anastasiou, E.K. Utilization of Industrial Byproducts for Enhancing the Properties of Cement Mortars at Elevated Temperatures. Sustainability 2021, 13, 12104. https://doi.org/10.3390/ su132112104

Academic Editor: Francesca Tittarelli

Received: 1 October 2021

Accepted: 28 October 2021

Published: 2 November 2021

Publisher's Note: MDPI stays neutral with regard to jurisdictional claims in published maps and institutional affiliations.

Copyright: (c) 2021 by the authors. Licensee MDPI, Basel, Switzerland. This article is an open access article distributed under the terms and conditions of the Creative Commons Attribution (CC BY) license (https:// creativecommons.org/licenses/by/ $4.0 /)$.

\begin{abstract}
The research on industrial byproducts, such as slags and fly ash, was intense during the last decades in the building sector. Apart from the environmental benefits coming from their exploitation, their application may lead to the production of cost effective and durable building materials, such as mortars and concrete. The impact of industrial byproducts on the resistance of materials to fire and elevated temperatures was assessed by many scientists, however, it is still an open field of research. In this study, locally available byproducts were investigated, including High Calcium Fly Ash (HCFA), coming from lignite-fired power plants, as well as Ladle Furnace Steel (LFS) slag and Electric Arc Furnace (EAF) slag aggregates, originating from the steel making industry. Six mortar compositions were manufactured with substitution of Ordinary Portland Cement (OPC) with HCFA and LFS slag $(20 \% w / w)$ and of natural aggregates with EAF slag $(50 \% w / w)$. At the age of 7,28 , and 90 days, the physico-mechanical properties of the specimens were recorded, while they were further exposed at elevated temperatures, concerning $200{ }^{\circ} \mathrm{C}, 400{ }^{\circ} \mathrm{C}, 600^{\circ} \mathrm{C}, 800^{\circ} \mathrm{C}$, and $1000^{\circ} \mathrm{C}$. After each exposure, their physico-mechanical and microstructure characteristics were identified. From the evaluation of the results, it was asserted that HCFA and EAF slag aggregates enhanced the overall performance of mortars, especially up to $600{ }^{\circ} \mathrm{C}$. LFS was beneficial only in combination with EAF slag aggregates.
\end{abstract}

Keywords: elevated temperatures; mortars; fly ash; slag; cement

\section{Introduction}

Concrete production worldwide requires increasing amounts of raw materials, while industrial byproducts can be used to meet this demand [1-4], either as supplementary cementitious materials, or as alternative aggregates, as already proven by several researchers [5-8]. High Calcium Fly Ash (HCFA) and Ladle Furnace Steel (LFS) slag are two alternative industrial byproducts that could be used as cement replacement $[9,10]$, while Electric Arc Furnace (EAF) slag could be used as alternative aggregate [11]. All three of them are produced at significant amounts at various regions around the world [12,13]. However, incorporating alternative materials in concrete requires extensive research regarding their short and long-term performance. Strength development, fresh state properties and durability are some aspects to be investigated, as well as performance under elevated temperatures.

Generally, composite materials undergo significant alterations at elevated temperatures, depending on their aggregates' type, mix design, moisture content, as well as state of preservation [14-17]. Their postfire degradation is also affected by the fire scenario exposed to, concerning heating rate, maximum temperature and exposure time $[18,19]$.

Exposure at extreme temperatures has a significant impact on both the binding system and aggregates of the matrix, as well as their interfacial transition zone (ITZ), leading to several physico-chemical alterations. Up to $100{ }^{\circ} \mathrm{C}$, free water evaporates, whereas capillary and chemically bound water is further removed [14,20,21]. Ettringite's decomposition occurs at $100-200^{\circ} \mathrm{C}$, portlandite's $\left(\mathrm{Ca}(\mathrm{OH})_{2}\right)$ dehydroxylation at $400-500{ }^{\circ} \mathrm{C}$, and 
calcite's $\left(\mathrm{CaCO}_{3}\right)$ decomposition at $700-800{ }^{\circ} \mathrm{C}$ [21-24]. At $550-600{ }^{\circ} \mathrm{C}$, the $\alpha$ - to $\beta$-quartz transformation of aggregates is recorded [21]. These alterations, influence both the physical and mechanical properties of the matrix, showing an extreme porosity increase (due to cracks formation) and significant strength decrease, minimized above $800{ }^{\circ} \mathrm{C}[15,25-28]$.

The utilization of industrial byproducts, such as FA, LFS, and EAF slag aggregates, seems a very promising alternative, apart from the environmental benefits, for producing fire resistant concrete and mortars. Relevant studies documented the positive impact deriving from the substitution of Ordinary Portland Cement (OPC) and natural aggregates by them, influencing both their postfire physical and mechanical properties $[15,25-31]$. Relevant research started in the 1970s, mostly concerning the influence of PFA concrete at elevated temperatures $[25,32]$, whereas it was enhanced during the last decades.

$\mathrm{Xu}$ et al. [15] investigated the positive influence of pulverized fly ash (PFA) in concrete after exposure at elevated temperatures by replacing 25 and $55 \%$ of OPC by PFA. Residual compressive strength was enhanced, as well as microhardness values. Rais et al. [29] studied the postfire positive effect of fly ash in cement mortars (replacement of 10, 25, 40, $50 \%$ of OPC by FA). Although FA presence decreased initial strength values, it enhanced mechanical properties after temperature exposure, especially up to the substitution of $25 \%$ of OPC, achieving a denser structure. Poon et al. [25] investigated the performance of concrete up to $800^{\circ} \mathrm{C}$, incorporating fly ash and blast furnace slag, stating that they both improved properties, especially mechanical strength, up to exposure at $600{ }^{\circ} \mathrm{C}$. Finally, $\mathrm{Ma}$ et al. [33] studied the behavior of cement mortars with a gradual replacement of cement (up to $15 \%$ ) by copper slag (CS), showing a strength increase up to $600{ }^{\circ} \mathrm{C}$.

Regarding the use of slag aggregates, Ameri et al. [28] studied the behavior of cementmortars at elevated temperatures with a gradual replacement of natural aggregates by CS. The best performance was achieved by replacing the $20 \%$ of aggregates by CS, resulting in a $24 \%$ increase of strength at $800{ }^{\circ} \mathrm{C}$, as well as a denser structure and lower microcracking. The use of more than $60 \%$ of CS had generally a negative influence on the mortar's properties. Netinger Grubeša et al. [26] investigated the residual properties of concrete using steel slag aggregates and FA up to $800{ }^{\circ} \mathrm{C}$, stating that at $500{ }^{\circ} \mathrm{C}$, steel slag is subjected to an extreme mineralogical transformation, negatively affecting mechanical properties.

According to the literature review, the influence of FA and CS was widely studied in cement mortars and concrete exposed at elevated temperatures, while there is a lack of relevant research on HCFA and LFS. Meanwhile, it is important for such studies to be implemented to fully understand the mechanisms occurring during exposure at extreme temperatures, as well as the impact of byproducts on the postfire properties of materials. In this study, an effort was made to investigate the influence of the partial substitution of OPC by HCFA and LFS $(20 \% w / w)$, as well as of natural aggregates by EAF slag aggregates $(50 \% w / w)$, on the physical, mechanical, and microstructure properties of cement mortars, before and after their exposure at elevated temperatures $\left(200-1000{ }^{\circ} \mathrm{C}\right)$. Results were comparatively evaluated and the effectiveness of the industrial byproducts' use was recorded.

\section{Materials and Methods}

\subsection{Constituents of the Trial Mixes}

For the needs of the experimental study, two series (A, B) of 3 trial mixes each, were manufactured and tested (totally 6 mixtures). In series $A$, natural aggregates of siliceous origin were used, in gradation $0-4 \mathrm{~mm}$, while in $B, 50 \% w / w$ of the natural aggregates were substituted by EAF slag aggregates of the same gradation. The binders concerned Portland cement CEM I42.5R, as well as HCFA and LFS that substituted the $20 \% w / w$ of CEM. The industrial byproducts were of local origin; HCFA originated from the lignite-fired power plants, while slags (LFS, EAF) from the steel making industry.

The Binder/Aggregate (B/A) ratio was $1 / 3$ by weight for all compositions, while the Water/Binder (W/B) ratio ranged from 0.42 to 0.48 , to achieve workability $15 \pm 0.5 \mathrm{~cm}$, according to ASTM C1437-13 [34]. For reducing the water demand, a polycarboxylate 
superplasticizer (sulphate free) was added ( $1 \% w / w$ of binders), in all mixtures. The manufacture and curing of the mortars were performed according to ASTM C109M-13 [34] and EN 196-1:1995 [35], while 18 prismatic specimens $(4 \times 4 \times 16 \mathrm{~cm})$ were manufactured for each composition.

The characteristics of the raw materials used are presented in Tables 1-3, where the constituents and proportions of the mortar mixtures are also shown.

Table 1. Characteristics of binders used in mortar mixes.

\begin{tabular}{|c|c|}
\hline Constituents & Characteristics \\
\hline CEM I42.5 R & $\begin{array}{cc}\text { Apparent Specific density }\left(\mathrm{kg} / \mathrm{m}^{3}\right) & 3140 \\
\text { Median Particle Size Diameter d50 }(\mu \mathrm{m}) & 12.22 \\
\text { Specific Surface Area }\left(\mathrm{m}^{2} / \mathrm{kg}\right) & 642 \\
\text { Chemical composition }(\% w / w): \mathrm{CaO}: 66.80, \mathrm{SiO}_{2}: 19.60, \mathrm{Al}_{2} \mathrm{O}_{3}: 3.74 \\
\mathrm{Fe}_{2} \mathrm{O}_{3}: 2.40, \mathrm{MgO}: 3.91, \mathrm{Na}_{2} \mathrm{O}: 0.57 \\
\mathrm{~K}_{2} \mathrm{O}: 1.08, \mathrm{LOI}: 1.91, \mathrm{Cl}^{-}: 0.03, \mathrm{SO}_{4}{ }^{-2}: 1.49\end{array}$ \\
\hline HCFA & $\begin{array}{cc}\text { Apparent Specific density }\left(\mathrm{kg} / \mathrm{m}^{3}\right) & 2420 \\
\text { Median Particle Size Diameter d50 }(\mu \mathrm{m}) & 39.92 \\
\text { Specific Surface Area }\left(\mathrm{m}^{2} / \mathrm{kg}\right) & 307 \\
\text { Chemical composition }\left(\% \text { w/w): } \mathrm{CaO}: 47.20, \mathrm{SiO}_{2}: 33.10, \mathrm{Al}_{2} \mathrm{O}_{3}: 7.29\right. \\
\mathrm{Fe}_{2} \mathrm{O}_{3}: 4.00, \mathrm{MgO}: 3.20, \mathrm{Na}_{2} \mathrm{O}: 1.00 \\
\mathrm{~K}_{2} \mathrm{O}: 0.53, \mathrm{LOI}: 3.75, \mathrm{Cl}^{-}: 0.04, \mathrm{SO}_{4}{ }^{-2}: 4.81\end{array}$ \\
\hline LFS slag & $\begin{array}{cc}\text { Apparent Specific density }\left(\mathrm{kg} / \mathrm{m}^{3}\right) & 2590 \\
\text { Median Particle Size Diameter d50 }(\mu \mathrm{m}) & 31.47 \\
\text { Specific Surface Area }\left(\mathrm{m}^{2} / \mathrm{kg}\right) & 496 \\
\text { Chemical composition }(\% w / w): \mathrm{CaO}: 50.70, \mathrm{SiO} 2: 32.40, \mathrm{Al} 2 \mathrm{O} 3: 1.36 \\
\mathrm{Fe}_{2} \mathrm{O}_{3}: 2.66, \mathrm{MgO}: 2.77, \mathrm{Na}_{2} \mathrm{O}: 0.78 & \\
\mathrm{~K}_{2} \mathrm{O}: 0.06, \mathrm{LOI}: 6.72, \mathrm{Cl}^{-}: 0.02, \mathrm{SO}_{4}{ }^{-2}: 0.43\end{array}$ \\
\hline
\end{tabular}

Table 2. Physical characteristics of aggregates used in mortar mixes.

\begin{tabular}{ccc}
\hline Aggregates & Characteristics \\
\hline & Gradation $(\mathrm{mm})$ & $0-4$ \\
Natural & Apparent specific density $\left(\mathrm{kg} / \mathrm{m}^{3}\right)$ & 2525 \\
(River/siliceous) & Water absorption $(\%)$ & 1.1 \\
& Porosity $(\%)$ & 0.46 \\
& Specific surface area $\left(\mathrm{m}^{2} / \mathrm{kg}\right)$ & 1585 \\
& Gradation $(\mathrm{mm})$ & $0-4$ \\
EAF slag & Apparent specific density $\left(\mathrm{kg} / \mathrm{m}^{3}\right)$ & 3330 \\
& Water absorption $(\%)$ & 3.0 \\
& Porosity $(\%)$ & 4.09 \\
& Specific surface area $\left(\mathrm{m}^{2} / \mathrm{kg}\right)$ & 13930 \\
\hline
\end{tabular}

Table 3. Constituents and proportions of mortar compositions.

\begin{tabular}{cccccccc}
\hline \multicolumn{1}{c}{ Raw Materials } & \multicolumn{5}{c}{ Mortar Compositions } \\
\cline { 5 - 8 } Parts of Weight & & A1 & A2 & A3 & B1 & B2 & B3 \\
\hline CEM I42.5 R & & 1 & 0.8 & 0.8 & 1 & 0.8 & 0.8 \\
High calcium fly ash & - & 0.2 & - & - & 0.2 & - \\
Ladle furnace slag & & - & - & 0.2 & - & - & 0.2 \\
Sand of siliceous origin (gradation 0-4 mm) & & & 3 & 3 & 1.5 & 1.5 & 1.5 \\
EAF steel slag aggregates (gradation 0-4 mm) & - & - & - & 1.5 & 1.5 & 1.5 \\
Superplasticizer (\% w/w of binders) & & 1 & 1 & 1 & 1 & 1 & 1 \\
W/B ratio & & 0.44 & 0.48 & 0.43 & 0.42 & 0.48 & 0.44 \\
Workability (cm) (ASTM C1437-13) & & 15.0 & 15.1 & 15.6 & 15.4 & 15.6 & 15.8 \\
\hline
\end{tabular}




\subsection{Testing Procedure}

At the age of 7, 28, and 90 days, the physical and mechanical properties of the mortars were tested. The tests concerned determination of porosity, absorption, and apparent specific gravity (RILEM CPC 11.3), water absorption coefficient due to capillary action according to ASTM C1585-13c (ASTM 2013c), dynamic modulus of elasticity based on ultrasounds according to ASTM C215-14 [36], and flexural and compressive strength following ASTM C348-14 [37] and ASTM C349-15 [38], respectively. Mechanical properties were tested in 3 specimens/composition, whereas physical in one specimen. The volume and mass changes of 2 specimens/composition, cured at RH $60 \pm 2 \%$ and $20 \pm 1{ }^{\circ} \mathrm{C}$, were determined in an effort to indicate their shrinkage deformations [21]. The obtained results concerned the mean values of the tested specimens.

At 28 days, two specimens from each mortar composition were subjected at elevated temperatures concerning $200{ }^{\circ} \mathrm{C}, 400{ }^{\circ} \mathrm{C}, 600^{\circ} \mathrm{C}, 800{ }^{\circ} \mathrm{C}$, and $1000^{\circ} \mathrm{C}$. Heating was performed in an electric furnace, in which the temperature rate and duration time were manually set. The heating scheme, heating-cooling rate, maximum temperature, exposure time, followed RILEM TC 200-HTC Recommendation [39], previous research work [19,21], and relevant studies $[17,28,40]$. The heating rate was $5^{\circ} \mathrm{C} / \mathrm{min}$, the exposure period (at the maximum temperature) $2 \mathrm{~h}$ and the cooling rate $2{ }^{\circ} \mathrm{C} / \mathrm{min}$. Figure 1 depicts the heating scheme conducted.

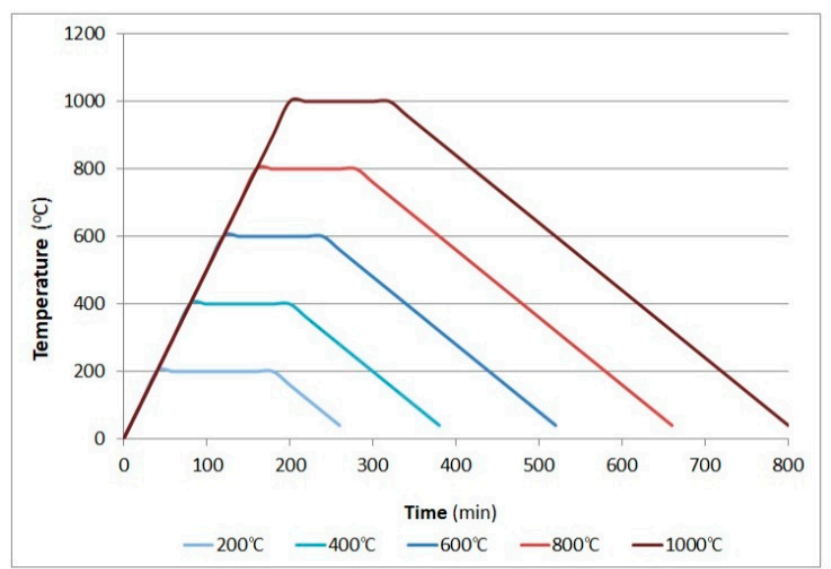

Figure 1. Heating scheme concerning heating-cooling rate and exposure time.

After the exposure at each temperature, the specimens were maintained for $24 \mathrm{~h}$ at laboratory conditions $\left(20 \pm 2{ }^{\circ} \mathrm{C}\right.$ and $\left.60 \pm 5 \% \mathrm{RH}\right)$. A series of tests were afterwards conducted, regarding volume and weight changes, determination of porosity, absorption, apparent specific gravity, dynamic modulus of elasticity, flexural and compressive strength. Macroscopic and microstructure observation was also assessed, with the latter to be performed with a stereoscope (Leica Wild M10, Leica Microsystems, Germany), assisted by image analysis (ProgRes).

Additionally, color identification according to the Munsel chart was realized, as well as mineralogical investigation through X-Ray diffraction (XRD). A 2D Phaser, 2nd Generation, diffractometer was used (Bruker Instruments), while X-ray diffraction patterns were recorded at $\mathrm{Cu} \mathrm{Ka}(30 \mathrm{kV}$ and $10 \mathrm{~mA}, \lambda=1.540 \AA)$, from $2^{\circ} \theta$ to $75^{\circ} \theta$, with step $0.02^{\circ}$ $\theta$ and time per step $0.4 \mathrm{~s}$. For the XRD functions, the software EVA V5.0 (Bruker) and the COD database (Crystallography Open Database) were used.

All results were comparatively evaluated to assess the mortars' behavior at the elevated temperatures and document the impact of EAF, HCFA, and LFS on their overall performance. 


\section{Results and Discussion}

\subsection{Reference Mortars}

\subsubsection{Water to Binder Ratio}

Regarding the water content of the mortars, compared to their respective workability (Table 3), it maybe asserted that the substitution of CEM by HCFA $(20 \% w / w)$ increased the water demand (A2), whereas LFS slightly reduced it (A3). The use of EAF steel slag aggregates (series B), which were used in a saturated-surface dry condition, also seemed to slightly decrease the water content, which was maintained at the same level with the natural aggregates' series (A).

These findings were in accordance with relevant studies on modified concrete and cement mortars, indicating that the substitution of $20-25 \% w / w$ OPC by FA or HCFA increases the water demand, resulting in a slightly lower consistency $[27,29,31]$. LFS maintains or even enhances workability, depending on its chemical composition and fineness [31,41], while steel slag aggregates may decrease [28] or increase [30] the water demand, according to their type, proportion, and gradation.

\subsubsection{Physical Properties}

In Figure 2, the volume and mass changes of the mortar specimens are presented to estimate their shrinkage deformations. Values were recorded up to $45-50 \mathrm{~d}$, showing the specimens' performance regarding volume and mass stability.
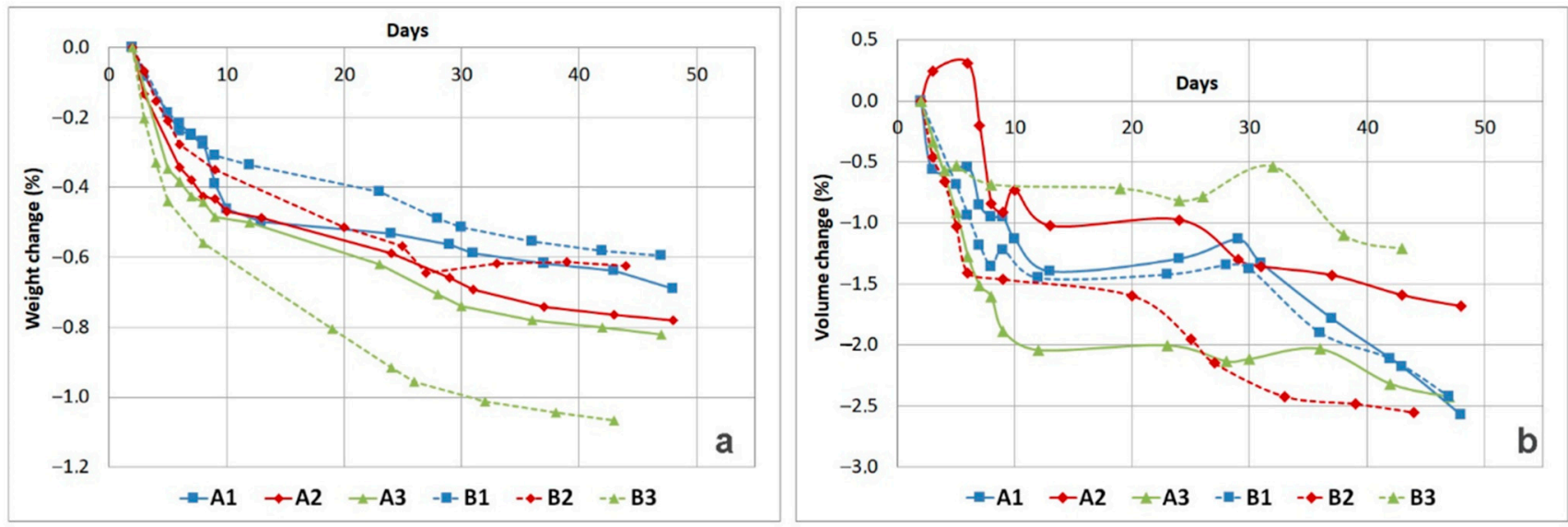

Figure 2. Shrinkage deformations of mortar specimens. (a) Weight changes; (b) volume changes.

Weight was reduced in all cases (Figure 2a), especially during the first 20 days, with the final loss to range from 0.6 to $1 \%$. The HCFA (A2) and LFS (A3) addition mainly affected the behavior of the mixtures after 20 days, slightly reducing the loss. Slag aggregates enhanced mass stability in the CEM (B1) and CEM-HCFA (B2) matrix, whereas they significantly reduced it in CEM-LFS (B3).

Volume changes (Figure $2 b$ ) were intense in the first 10 days, where various fluctuations were recorded. They mostly concerned volume reduction (1.0-2.5\%), except for composition A2 that showed a slight expansion in the first 6 days. Generally, the HCFA addition (A2) enhanced volume stability, in accordance to literature [27]. LFS (A3) induced changes, while slag aggregates significantly ameliorated the matrix (B3), which had the best performance. They slightly affected the reference mortar (B1) and worsened the behavior of B2 (CEM-HCFA).

These observations were in accordance with relevant literature and former experimental results [30], indicating that EAF slag aggregates may have a beneficial effect on the volume and mass stability of the mixtures.

From the evaluation of the trial mixes physical properties (Table 4), it was asserted that there were fluctuations of the results, among the compositions and their testing dates. 
The $28 \mathrm{~d}$ and $90 \mathrm{~d}$ testing values showed some differences, mainly concerning a slight decrease of the $90 \mathrm{~d}$ porosity and absorption. Apparent specific gravity slightly increased, while the capillary absorption index was significantly reduced.

Table 4. Physical properties of mortar compositions at 28 and 90 days.

\begin{tabular}{|c|c|c|c|c|c|c|c|c|}
\hline \multirow{2}{*}{$\begin{array}{l}\text { Mortar } \\
\text { Code }\end{array}$} & \multicolumn{2}{|c|}{$\begin{array}{l}\text { Porosity } \\
(\%)\end{array}$} & \multicolumn{2}{|c|}{$\begin{array}{l}\text { Absorption } \\
(\%)\end{array}$} & \multicolumn{2}{|c|}{ Ap. Spec. Gravity } & \multicolumn{2}{|c|}{$\begin{array}{l}\text { Capillary Absorption } \\
\text { Index }\left(\mathrm{kg} / \mathrm{m}^{2} \cdot \mathrm{min}^{0.5}\right)\end{array}$} \\
\hline & $28 \mathrm{~d}$ & $90 \mathrm{~d}$ & $28 \mathrm{~d}$ & $90 \mathrm{~d}$ & $28 \mathrm{~d}$ & $90 \mathrm{~d}$ & $28 \mathrm{~d}$ & $90 \mathrm{~d}$ \\
\hline A1 & 6.49 & 6.35 & 2.73 & 2.62 & 2.37 & 2.39 & 0.108 & 0.054 \\
\hline $\mathrm{A} 2$ & 7.46 & 7.32 & 3.21 & 3.01 & 2.33 & 2.34 & 0.147 & 0.062 \\
\hline A3 & 7.81 & 7.78 & 3.30 & 3.15 & 2.37 & 2.36 & 0.072 & 0.075 \\
\hline B1 & 6.91 & 6.58 & 2.70 & 2.52 & 2.56 & 2.58 & 0.117 & 0.093 \\
\hline B2 & 8.41 & 7.95 & 3.48 & 3.32 & 2.41 & 2.47 & 0.151 & 0.111 \\
\hline B3 & 9.39 & 9.01 & 3.85 & 3.58 & 2.44 & 2.60 & 0.129 & 0.076 \\
\hline
\end{tabular}

Generally, the HCFA addition (A2) increased porosity and absorption, as well as capillary absorption. LFS (A3) further increased porosity and absorption (around 25\%), whereas decreased apparent specific gravity and capillary absorption. As expected, the use of steel slags, increased apparent specific gravity in all cases (around 15-20\%), due to their higher specific gravity (Table 2). The slight increase of porosity and absorption values may be attributed to the slag aggregates' pores, as presented in Table 2 and identified by literature $[26,30]$.

The experimental results were in accordance with relevant studies regarding both the density increase due to steel slag aggregates $[26,28,30]$ and the fluctuations recorded by the HCFA and LSF addition $[15,25,27]$. Xu et al. [15] recorded a slight porosity decrease by the substitution of $25 \% w / w$ of OPC with PFA, while Poon et al. [25] identified a higher reduction, related also to the pores size decrease [42]. Duran-Herrera et al. [27] recorded a slight decrease of density due to FA addition, related to the higher water demand, while Netinger-Grubeša et al. [26], indicated a density decrease due to the slag aggregates addition (around 5-20\%).

\subsubsection{Mechanical Properties}

The development rate of flexural and compressive strength of the mortars is presented in Figure 3, depicting the values attained at 7, 28, and 90 days. The rate was intense for flexural strength up to 90 days, while it was stabilized at 28 days for compressive. According to the results, slag aggregates significantly enhanced strength, with an increase around $25 \%$ for flexural strength ( $11.5 \mathrm{MPa}$ ) and $50 \%$ for compressive (58 MPa), an increase also highlighted in literature [28,30,43,44]. Ameri et al. [28] indicated that the positive impact of slag aggregates on flexural strength is based on their physical characteristics.

HCFA addition (A2) resulted in an increase of the 7 and $28 \mathrm{~d}$ flexural strength, compared to that of the reference mortar (A1). It slightly reduced compressive strength values at the same ages, whereas the $90 \mathrm{~d}$ compressive strength was at the same level with the reference mortar (A1). Strength was significantly enhanced by slag aggregates (B2) at all ages, showing a final increase of $7 \%$ for flexural and 30\% for compressive strength. Results were in alliance with literature, indicating a lower strength development rate by the FA addition $[29,31,45]$, as well as the positive impact of slag aggregates in strength $[28,30]$.

Respectively, LFS (A3) showed a higher strength development rate compared to that of A1, showing lower flexural strength final values $(7 \mathrm{MPa})$ and the same compressive strength (58 MPa), according to former research work [31,41]. Slag aggregates also enhanced strength, however, at a lower level compared to that of compositions B1 and B2. 

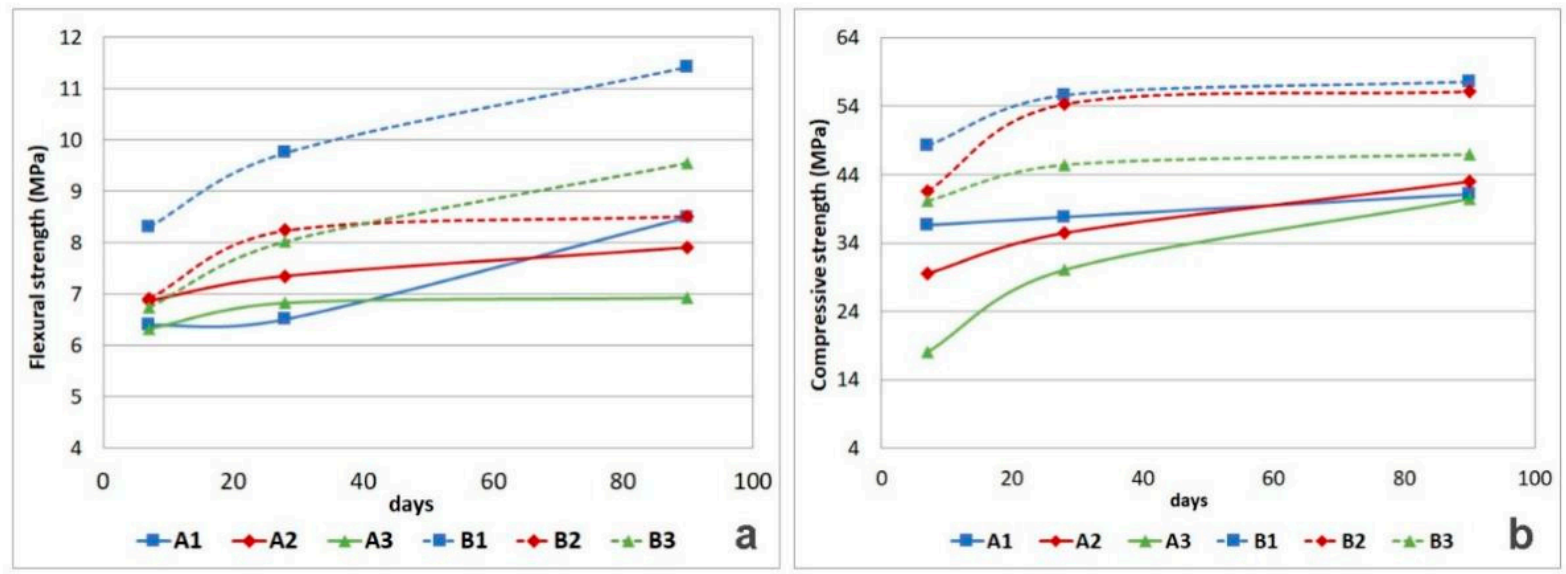

Figure 3. Strength development of mortar specimens (7, 28, 90 d). (a) Flexural strength; (b) compressive strength.

Generally, the proportion, fineness, and composition of FA and LFS are crucial parameters in determining the mechanical properties of modified mortars and concrete, leading either to strength loss or enhancement $[15,25,31,41,45]$.

\subsection{Exposure at Elevated Temperatures}

\subsubsection{Macroscopic Observation}

In Figure 4, the postfire structure of the specimens is presented, while in Table 5 their color changes, according to the Munsel chart. Short et al. [22], reported that when heated at $300-600{ }^{\circ} \mathrm{C}$, concrete turns reddish, whitish-grey at $600-900{ }^{\circ} \mathrm{C}$, while at $900-1000{ }^{\circ} \mathrm{C}$ it gains a buff color. These hue alterations maybe attributed to the gradual water evaporation, the dehydration of the cement paste, as well as the aggregates' transformations [22]. According to former experimental work [21], an enlightenment of the hue takes place at $200{ }^{\circ} \mathrm{C}$ (related to humidity loss), while at $600{ }^{\circ} \mathrm{C}$ dark (grey) stains are created in the surface of the specimens, linked with the $\mathrm{CO}_{2}$ combustion taking place at this temperature range. The initial color reappears at $1000^{\circ} \mathrm{C}$, in a significantly lighter hue.

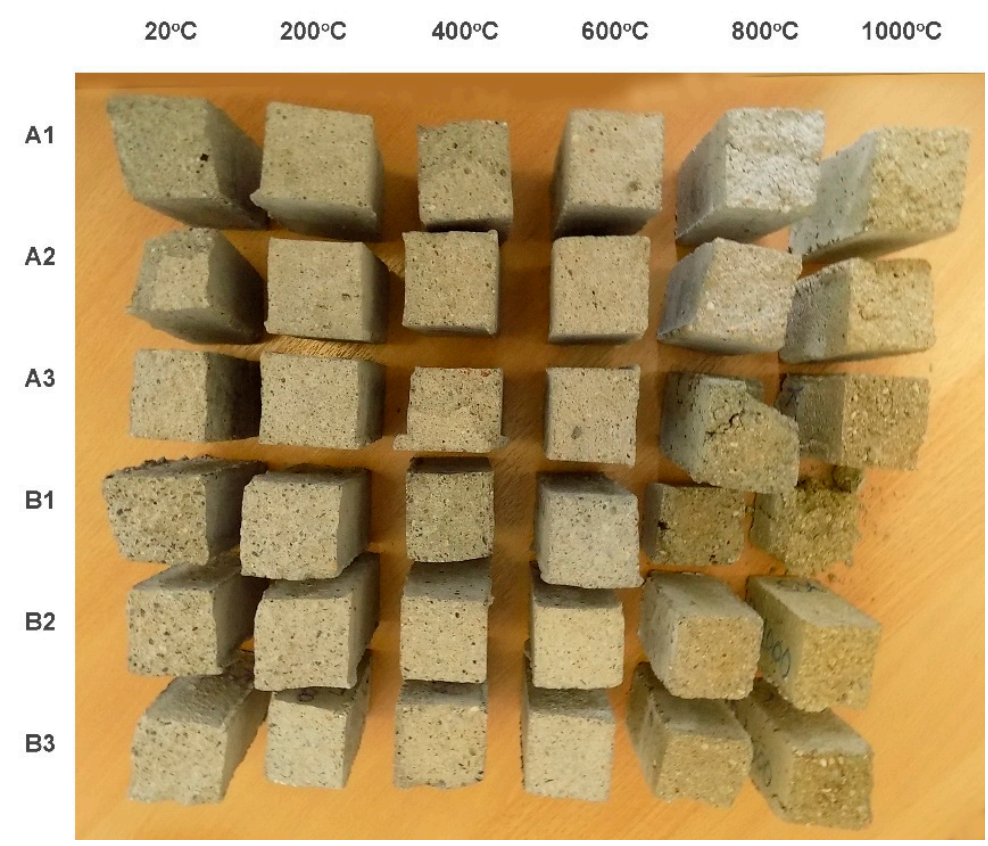

Figure 4. Macroscopic observation of mortar specimens exposed at elevated temperatures. 
Table 5. Color changes of exposed mortar specimens, according to Munsel chart.

\begin{tabular}{|c|c|c|c|c|c|}
\hline Mortar Code & $200{ }^{\circ} \mathrm{C}$ & $400{ }^{\circ} \mathrm{C}$ & $600{ }^{\circ} \mathrm{C}$ & $800{ }^{\circ} \mathrm{C}$ & $1000{ }^{\circ} \mathrm{C}$ \\
\hline A1 & $\begin{array}{l}\text { Gley } 27 / 1 \text { light } \\
\text { greenish gray }\end{array}$ & $\begin{array}{c}\text { Gley } 26 / 1 \text { bluish } \\
\text { gray }\end{array}$ & \multirow{3}{*}{$\begin{array}{c}\text { 5Y } 7 / 1 \text { light } \\
\text { gray }\end{array}$} & $\begin{array}{l}\text { Gley } 27 / 1 \text { light } \\
\text { bluish gray }\end{array}$ & $\begin{array}{l}2.5 Y \text { Y } / 3 \text { light } \\
\text { yellowish brown }\end{array}$ \\
\hline $\mathrm{A} 2$ & Gley 17 / light gray & $\begin{array}{l}\text { Gley } 27 / 1 \text { light } \\
\text { bluish gray }\end{array}$ & & $\begin{array}{l}5 Y 7 / 1 \text { light } \\
\text { gray }\end{array}$ & $2.5 Y 7 / 2$ light gray \\
\hline A3 & \multicolumn{2}{|c|}{ Gley $17 /$ light gray } & & & \\
\hline B1 & Gley $26 / 1$ bluish gray & Gley $16 /$ gray & $\begin{array}{l}\text { Gley } 17 / \text { light } \\
\text { gray }\end{array}$ & 2.5Y 6/1 gray & $\begin{array}{l}2.5 \mathrm{Y} 6 / 2 \text { light } \\
\text { brownish gray }\end{array}$ \\
\hline B2 & \multirow{2}{*}{\multicolumn{2}{|c|}{ Gley 2 7/1 light bluish gray }} & \multirow[b]{2}{*}{$\begin{array}{c}\text { 5Y } 7 / 1 \text { light } \\
\text { gray }\end{array}$} & & \\
\hline B3 & & & & $2.5 Y 7 / 2$ gray & $\begin{array}{l}2.5 Y 5 / 2 \text { grayish } \\
\text { brown }\end{array}$ \\
\hline
\end{tabular}

In this study (Table 5 and Figure 4), respective color changes were recorded at the heated specimens, ranging from Gley 17 /light gray to $2.5 Y 5 / 2$ grayish brown. At ambient temperature, the color of series B was slightly darker, due to the slag aggregates' presence. At $200^{\circ} \mathrm{C}$, the color became brighter, probably due to the humidity loss. It was maintained or became slightly darker at $400{ }^{\circ} \mathrm{C}$, while at $600{ }^{\circ} \mathrm{C}$, some grey stains were recorded in the surface of the specimens, linked with the $\mathrm{CO}_{2}$ combustion [21]. Internally, specimens presented a more uniform shade, however darker than that of $400^{\circ} \mathrm{C}$. At $800^{\circ} \mathrm{C}$, the hue became even darker, whereas it was more vivid compared to $400{ }^{\circ} \mathrm{C}$, while at $1000{ }^{\circ} \mathrm{C}$, a brownish hue was detected in all specimens.

Comparing the compositions, the smaller alterations were recorded in A2 and B2 (varying from Gley $26 / 1$ bluish gray to $2.5 \mathrm{Y} 7 / 2$ light gray and 2.5Y 6/2 light brownish gray) and the more intense in A1 and B1. Generally, the HCFA presence reduced color changes during heating, while the more intense alterations were detected at $800-1000{ }^{\circ} \mathrm{C}$.

The structure of the specimens seemed to be maintained in most cases and at all tested temperatures, as presented in Figure 4 . Up to $600{ }^{\circ} \mathrm{C}$, their stability was kept, while at $800{ }^{\circ} \mathrm{C}$, cracks were detected in all compositions except $\mathrm{A} 2$, which presented the better state. A1, A3, and B1 showed the worst condition. At $1000^{\circ} \mathrm{C}$, cracks were more intense in A1, whereas B1 almost lost its stability. Compositions A2 and B2 showed the better state, showing that the addition of HCFA retained the structural stability of mortars.

\subsubsection{Physical Properties}

The weight loss of the exposed specimens, presented in Figure $5 \mathrm{a}$, showed a linear decrease up to $800^{\circ} \mathrm{C}$, while at $1000^{\circ} \mathrm{C}$, mass stabilization was recorded. The highest loss varied from 9.5 to $11.3 \%$, whereas the most prone compositions seemed to be B2 and B3. On the contrary, the lower decrease was seen in $\mathrm{A} 3$ and $\mathrm{B} 1$ (up to $600^{\circ} \mathrm{C}$ ). Compared to that of the reference mortar (A1), the presence of LFS seemed to be beneficial. Results were in accordance with literature $[17,21,28,33,40]$, indicating a maximum mass loss around $8-16 \%$.

According to Horszczaruk et al. [17], mass loss is attributed to the evaporation of free and bonded water from the matrix, taking into account that ettringite's dehydroxylation occurs at $80-150{ }^{\circ} \mathrm{C}, \mathrm{CSH}$ at $300{ }^{\circ} \mathrm{C}$, and CAH at $550{ }^{\circ} \mathrm{C}$. Janotka and Nurnbergerova [46] identified that the most extreme changes are observed up to $300-400{ }^{\circ} \mathrm{C}$. The aggregate properties, especially related to water retentivity, may influence water release, determining mass loss [17]. Netinger-Grubeša et al. [26] indicated that the addition of slag aggregates induces weight loss, especially at the temperature range of $200-600{ }^{\circ} \mathrm{C}$, while at $600-800{ }^{\circ} \mathrm{C}$, changes are reduced, mainly related to the aggregate transformations.

Ameri et al. [28], also correlated mass loss with the temperature range, attributing it to the water evaporation and deterioration of the pore structure. Up to $200^{\circ} \mathrm{C}$, it is linked with the presence of free water in the mortar matrix and to the compounds dehydroxylation at $200-400{ }^{\circ} \mathrm{C}$ [33]. At $600-800{ }^{\circ} \mathrm{C}$, the breakdown of the Si-O-Al bonds of the calcium 
alumino-silicate hydrate (CASH) gel further deteriorates the structure. The addition of slag aggregates leads to a reduction of mass loss due to the enhancement of the aggregate-paste thermal compatibility $[28,47]$.
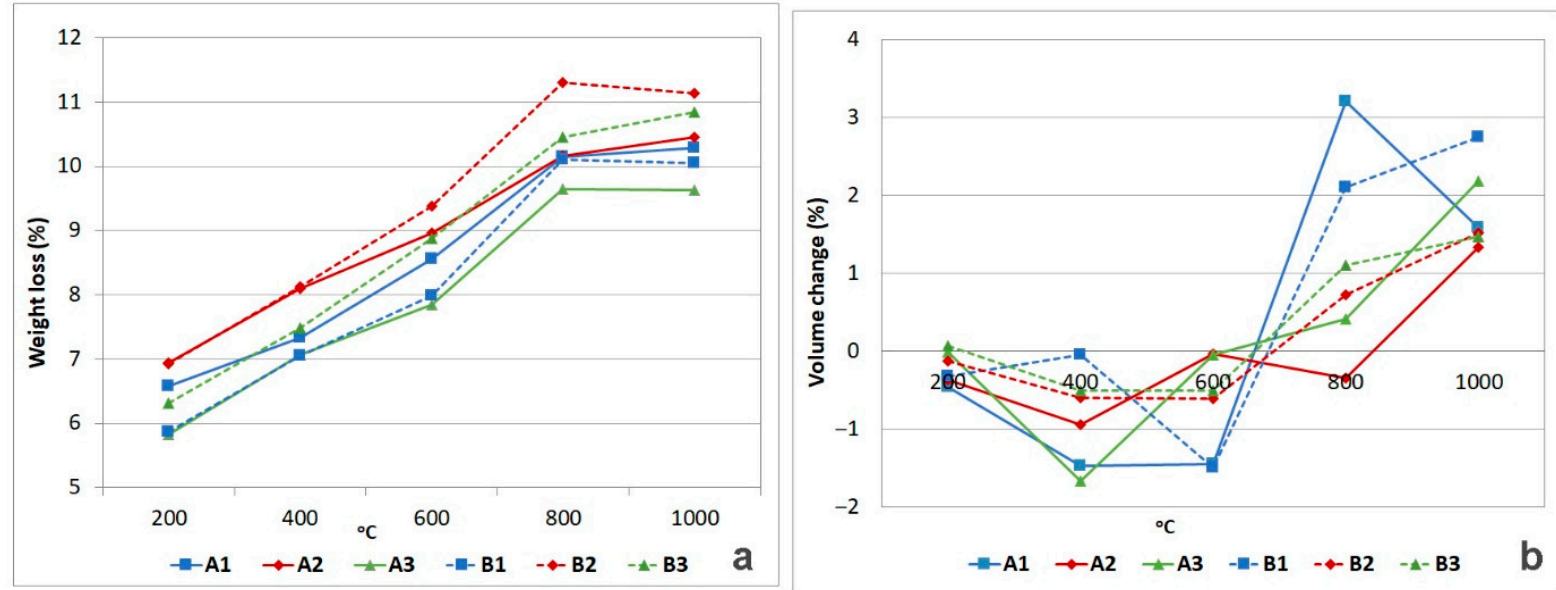

Figure 5. Weight and volume changes of specimens exposed at elevated temperatures. (a) Weight loss; (b) volume changes.

Volume changes showed extreme fluctuations (Figure $3 b$ ), with values to range from -1.5 to $3 \%$. In all cases, it was detected that $600{ }^{\circ} \mathrm{C}$ was a crucial stage beyond which the mortars' behavior changed in a more intense way. Up to this temperature, volume reduction was recorded, while above it there was extreme expansion. This phenomenon could be attributed to the physico-chemical actions realized at this temperature range, such as the decomposition of the amorphous calcite species $\left(500-630^{\circ} \mathrm{C}\right)$ and the $\alpha$-quartz to $\beta$-quartz transformation [21].

The more extreme alterations were recorded in the reference mortar (A1, B1) and the lower in the HCFA addition and were in accordance with the macroscopic observations. HCFA and LFS seemed to maintain volume, as well as the slag aggregates addition. Xiao et al. [48], indicated that after exposure at elevated temperatures, the mortar structure becomes loose, due to the pores' expansion and the evaporation of free and bonded water. During cooling, a proportion of the ionized $\mathrm{CaO}$ (decomposed from $\left.\mathrm{Ca}(\mathrm{OH})_{2}\right)$, may absorb water, transformed again to $\mathrm{Ca}(\mathrm{OH})_{2}$ and resulting to the expansion of the concrete volume [48].

Porosity, absorption, and apparent specific gravity, measured up to $600{ }^{\circ} \mathrm{C}$ (Figure 6), showed almost the same trend for all compositions, with porosity and absorption to be significantly increased (up to 3 times) at the highest temperature. HCFA and LFS addition presented slightly higher values, compared to that of the reference mortar, whereas slag aggregates seemed to slightly reduce changes. Apparent specific gravity (Figure 6c) was linearly decreased for all compositions, around $10-15 \%$. The highest decrease was recorded in the reference mortar (A1), while the lower reduction was shown in series B.

Results were in accordance with relevant studies, indicating an almost triple increase of porosity and absorption at the highest temperatures [21]. Netinger-Grubesa et al. [26], also testified a porosity increase due to heating, related with the formation of cracks, due to stresses encountered from the compounds' dehydration and the aggregates' thermal expansion. The thermal changes are lower in slag aggregates compared to that of the natural ones [26]. Additionally, Poon et al. [25] indicated a significant increase of porosity and average pore size of the mixtures at $600^{\circ} \mathrm{C}$, with a positive impact of $\mathrm{FA}$ and granulated blast furnace slag addition. 

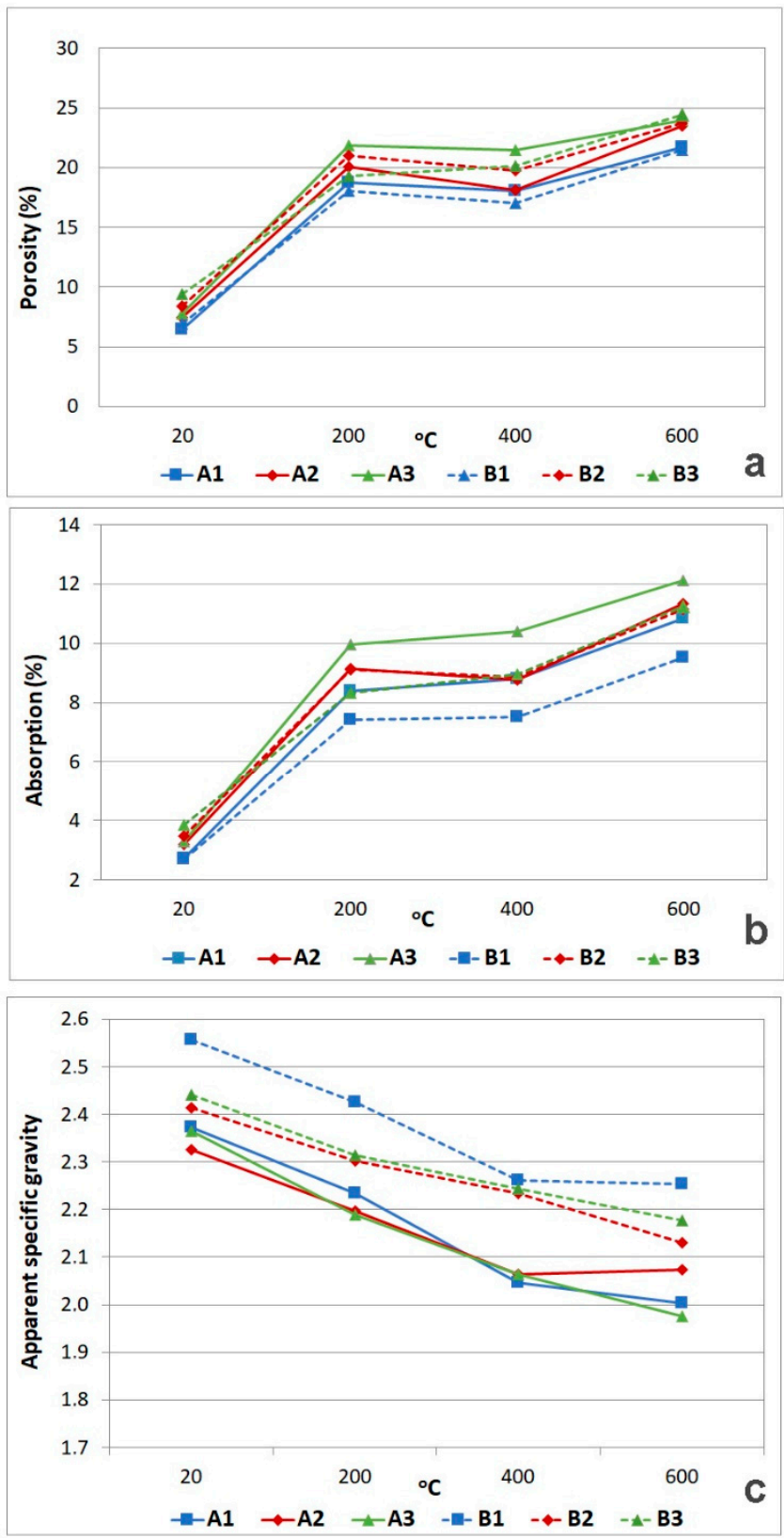

Figure 6. Physical properties of mortars exposed at elevated temperatures. (a) Porosity; (b) absorption; (c) apparent specific gravity.

\subsubsection{Mechanical Properties}

Mechanical properties were influenced by the temperature rise, according to the mortar type. Dynamic modulus of elasticity (Figure 7a) showed an intense (linear) values' decrease up to $800{ }^{\circ} \mathrm{C}$, where it was minimized. The initial results, ranging from to $35-47 \mathrm{GPa}$ at ambient temperature, were reduced around $30-35 \%$ at $200{ }^{\circ} \mathrm{C}, 57-68 \%$ at $400{ }^{\circ} \mathrm{C}, 70-82 \%$ at $600{ }^{\circ} \mathrm{C}, 93-95 \%$ at $800{ }^{\circ} \mathrm{C}$, and $96-97 \%$ at $1000{ }^{\circ} \mathrm{C}$, reaching $1-1.8 \mathrm{GPa}$. HCFA addition (A2) seemed to maintain modulus of elasticity at all temperatures, whereas LFS decreased values around $15 \%$, taking into account the lower initial results. Slag aggregates, on the other hand, enhanced modulus of elasticity at all temperatures (around $15-20 \%)$ and for all mixes. 

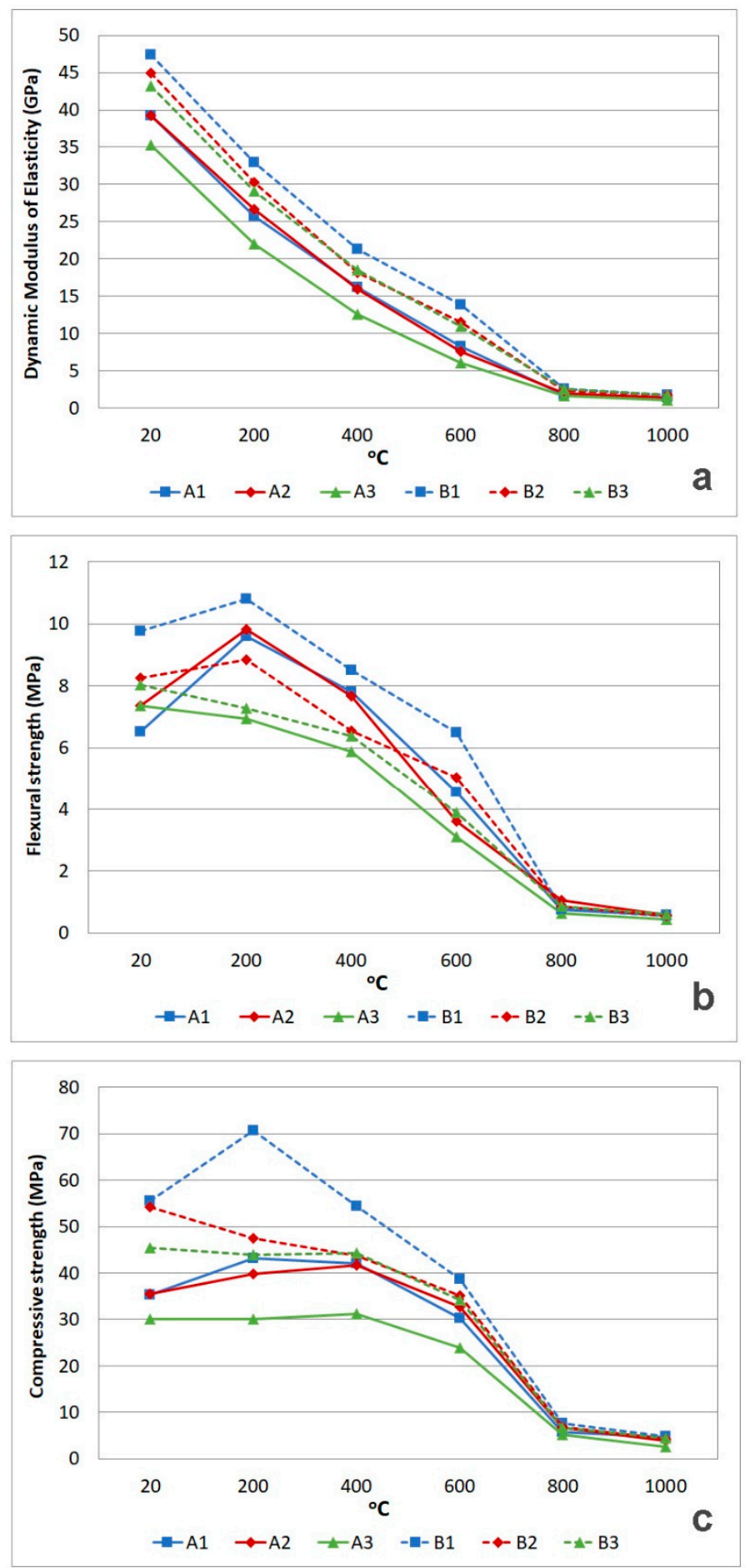

Figure 7. Mechanical properties of mortars exposed at elevated temperatures. (a) Dynamic modulus of elasticity; (b) flexural strength; (c) compressive strength.

Results were in alliance with relevant studies [21,26,49,50], indicating a temperaturedependent, linear decrease of modulus of elasticity, with minimization of values above $800{ }^{\circ} \mathrm{C}$. Netinger-Grubeša et al. [26] stated that between $100-600^{\circ} \mathrm{C}$ modulus is reduced around $70 \%$, while above $600{ }^{\circ} \mathrm{C}$, the reduction rate is decreased. This observation confirmed the results of the present study, documenting a higher reduction rate between $200-600{ }^{\circ} \mathrm{C}$. The modulus loss trend may be related to excessive thermal stresses of constituents, disintegration of the hydrated compounds and bonds' breakage in the microstructure of the paste [21]. 
Flexural strength (Figure $7 \mathrm{~b}$ ) showed an increase at $200{ }^{\circ} \mathrm{C}$ (up to $45 \%$ ), except for the case of LFS presence (A3, B3), with the higher increase to be reported in compositions A1 and A2. This phenomenon was testified by literature $[17,18,21,33]$ and could be linked with the loss of free and capillary water, leading to a denser structure. At $400{ }^{\circ} \mathrm{C}$, strength was almost at the initial level and was significantly decreased at $600{ }^{\circ} \mathrm{C}$ (around 30-50\%). At $800{ }^{\circ} \mathrm{C}$, all values were significantly reduced (around 85-90\%) and were minimized at $1000{ }^{\circ} \mathrm{C}$, attaining almost the $5 \%$ of the initial strength.

The impact of high temperatures $\left(>600^{\circ} \mathrm{C}\right)$ on flexural strength, is mostly related to micro-cracking phenomena, due to the gradual decomposition of the hydration compounds of the paste $\left(\mathrm{Ca}(\mathrm{OH})_{2}, \mathrm{CSH}, \mathrm{CASH}\right.$ gel) $[21,28]$. The loss of bound water, the chemical bonds' breakage, the intensive shrinkage, and the aggregates' transformations are the key factors leading to the strength loss at the temperature range of $600{ }^{\circ} \mathrm{C}[21,28,33]$.

Steel slag aggregates seemed to enhance strength at all temperatures (around 10-20\%), being in accordance with relevant studies [28,31,33]. This improvement could be attributed to the higher hardness of EAF slag aggregates, compared to that of the natural ones, as well as to their firm ITZ with the cement paste [30]. Ameri et al. [28] reported that the substitution up to $60 \%$ of natural aggregates by CS may increase the postfire flexural strength of the mixtures around $12-28 \%$.

HCFA presence (A2), seemed to significantly enhance flexural strength up to $400{ }^{\circ} \mathrm{C}$, compared to that of the reference mortar. This was in alliance with relevant literature $[15,26,45]$, indicating the beneficial effect of FA during heating. Xu et al. [15] and Netinger-Grubesa et al. [26] reported that FA enhances the performance of concrete at elevated temperatures, since it may reduce the thermal cracks occurring due to the decomposition of $\mathrm{Ca}(\mathrm{OH})_{2}$ (realized around $400^{\circ} \mathrm{C}$ ).

Compressive strength (Figure 7c) was increased (series A, B1) or maintained (B2, B3) up to $400{ }^{\circ} \mathrm{C}$. The increase ranged around $12-27 \%$ at $200{ }^{\circ} \mathrm{C}$ and $3-18 \%$ at $400{ }^{\circ} \mathrm{C}$. The initial strength, varying from to 30 to $55 \mathrm{MPa}$ at ambient temperature, was further reduced, around $10-35 \%$ at $600{ }^{\circ} \mathrm{C}, 80-87 \%$ at $800{ }^{\circ} \mathrm{C}$, and $86-92 \%$ at $1000{ }^{\circ} \mathrm{C}$, reaching 2.6-4.7 $\mathrm{MPa}$. HCFA (A2) seemed to maintain the initial compressive strength values, showing a lower reduction at $600-800^{\circ} \mathrm{C}$, whereas LFS resulted in a more intense strength loss. EAF slag aggregates, on the other hand, significantly enhanced the mortars' residual strength, while they were more effective in the cement matrix (B1), showing the highest values at all temperatures.

The experimental results were in agreement with literature, both concerning the behavior of cement mortars, as well as the impact of industrial byproducts $[17,21,24,30,33]$. The enhancement of residual strength due to slag aggregates was also documented by researchers $[28,30,33,45]$, indicating a significant residual strength improvement up to $600{ }^{\circ} \mathrm{C}$.

The strength increase, up to $400{ }^{\circ} \mathrm{C}$, could be related to the evaporation of free, capillary and bonded water that resulted in a dense structure, since the increasing vapor pressures in the gel pores were not capable to initiate cracks, reducing strength [21]. The dihydroxylation of portlandite and the presence of calcite species could have also enhanced the matrix [21]. The extreme drop of strength at $800{ }^{\circ} \mathrm{C}$ could be correlated with the $\alpha$ - to $\beta$ quartz transformation taking place at $600-650{ }^{\circ} \mathrm{C}$, as well as the intense volume alterations recorded beyond this temperature limit [21,24,45].

The flexural/compressive strength ratio, presented in Figure 8, showed fluctuations, which were, however, decreased with the temperature increase. The lower changes were recorded with the slag aggregates' presence (series B), whereas the more extreme ones in composition A2. The ratio seemed to be increased at $200{ }^{\circ} \mathrm{C}$ for most compositions (except B1, B3) and was further reduced up to 15-35\%. The smaller decrease was recorded for HCFA and LFS addition, especially with the slag aggregates' presence. 


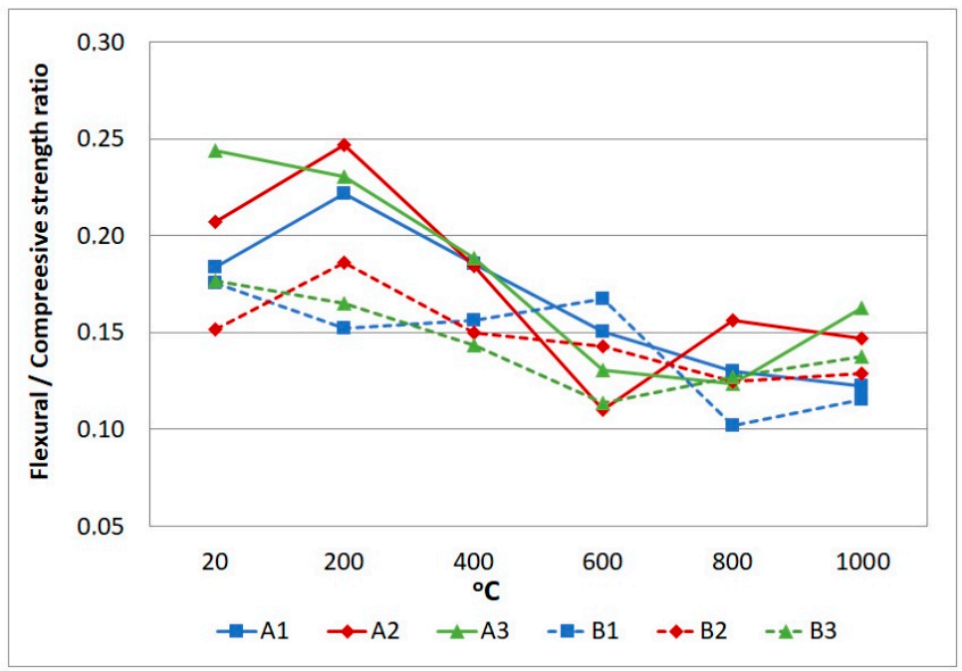

Figure 8. Flexural/compressive strength ratio of mortars exposed at elevated temperatures.

The decrease of the flexural/compressive strength ratio during elevated temperatures, also confirms that flexural strength is more prone to heating, due to microcrack formation (thermal stresses and pressure attained in the gel pores). From the evaluation of the results, it may be concluded that industrial byproducts, such as HCFA, LFS, and EAF slag aggregates may stabilize the residual flexural/compressive strength ratio of mortars, for the benefit of their postfire integrity.

\subsubsection{Microstructure Characteristics}

According to Figure 9, where the microstructure of the mortars after their exposure at elevated temperatures is presented, it may be asserted that the remarks regarding their physical properties are testified. Porosity, both regarding the proportion and pore size, was gradually increased, whereas intense cracking was detected at 800 and $1000{ }^{\circ} \mathrm{C}$. At these temperatures, the structure became brittle in most cases, with interconnected voids. Color changes were also identified and were more extreme after $600{ }^{\circ} \mathrm{C}$.

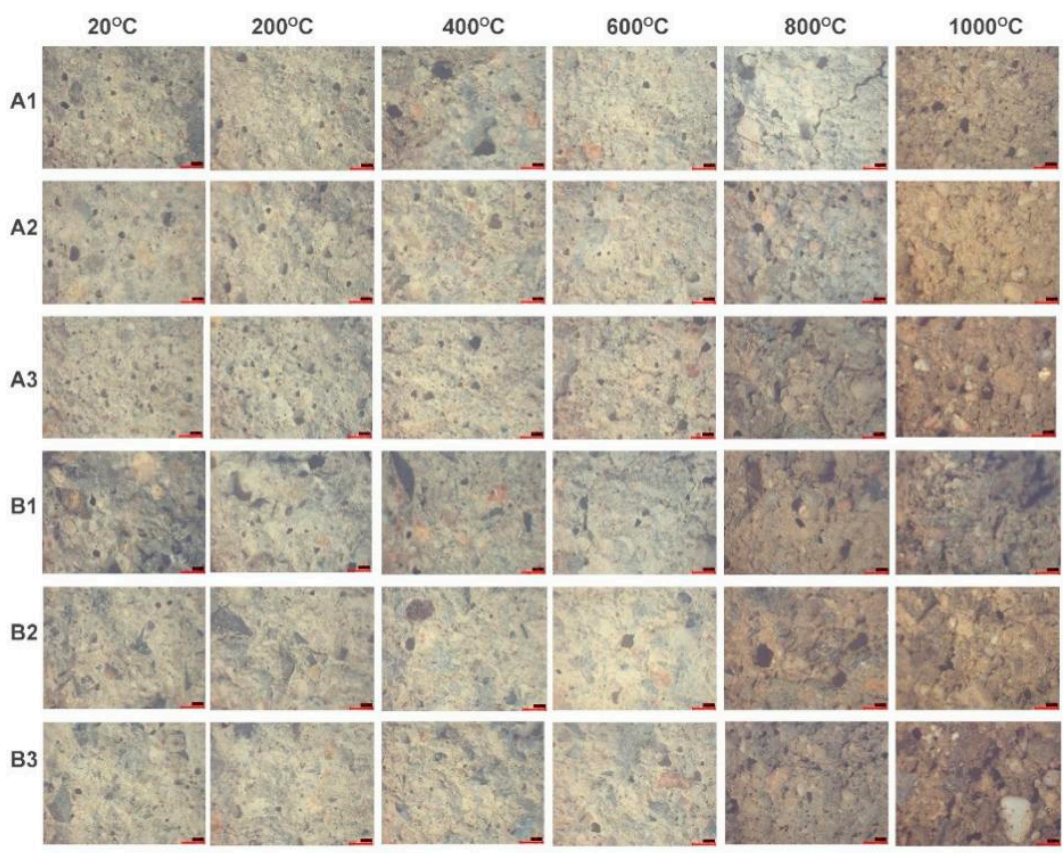

Figure 9. Microscopic photos of mortars exposed at elevated temperatures. 
At ambient temperature, the pore main diameter ranged from 100 to $300 \mu \mathrm{m}$, with the larger pores to be found in compositions A2 and B2. The addition of slag aggregates contributed to a pore size decrease and creation of a denser structure, being in accordance with the experimental results of this study. At $200{ }^{\circ} \mathrm{C}$, the pores proportion and size were increased (especially in compositions A1, A2, A3) and were more intense in higher temperatures. Slag aggregates seemed to enhance the matrix at all temperatures, whereas the plain mixture (A1) and the LFS addition (A3) showed the more extreme changes.

Figure 10 shows the diffractograms of compositions A1, A2 and B1 at ambient temperature and after their exposure at $400{ }^{\circ} \mathrm{C}$. The detected mineralogical phases of portlandite (COD 9000113) and calcite (COD 9009667), were attributed to the cement paste, whereas quartz (COD 1011172) and albite (COD 9002199) presence was related to aggregates. Portlandite proportion was reduced in all cases after exposure at $400{ }^{\circ} \mathrm{C}$ (around $30-50 \%$ ), while calcite was increased, according to former research work [21]. The addition of slag aggregates (B1), resulted to the formation of magnesite $\left(\mathrm{CMgO}_{3} / \mathrm{COD} 9007692\right)$ and magnetite $\left(\mathrm{Fe}_{2} \mathrm{O}_{3} / \mathrm{COD} 9013533\right)$ that were also reduced at $400{ }^{\circ} \mathrm{C}$. According to Ma et al. [33], copper slag is rich of ferrous minerals, such as fayalite $\left(\mathrm{Fe}_{2} \mathrm{SiO}_{4}\right)$ and magnetite $\left(\mathrm{Fe}_{3} \mathrm{O}_{4}\right)$ that could be activated by portlandite $\left(\mathrm{Ca}(\mathrm{OH})_{2}\right)$, forming $\mathrm{Fe}(\mathrm{OH})_{3} / \mathrm{Fe}(\mathrm{OH})_{2}$.
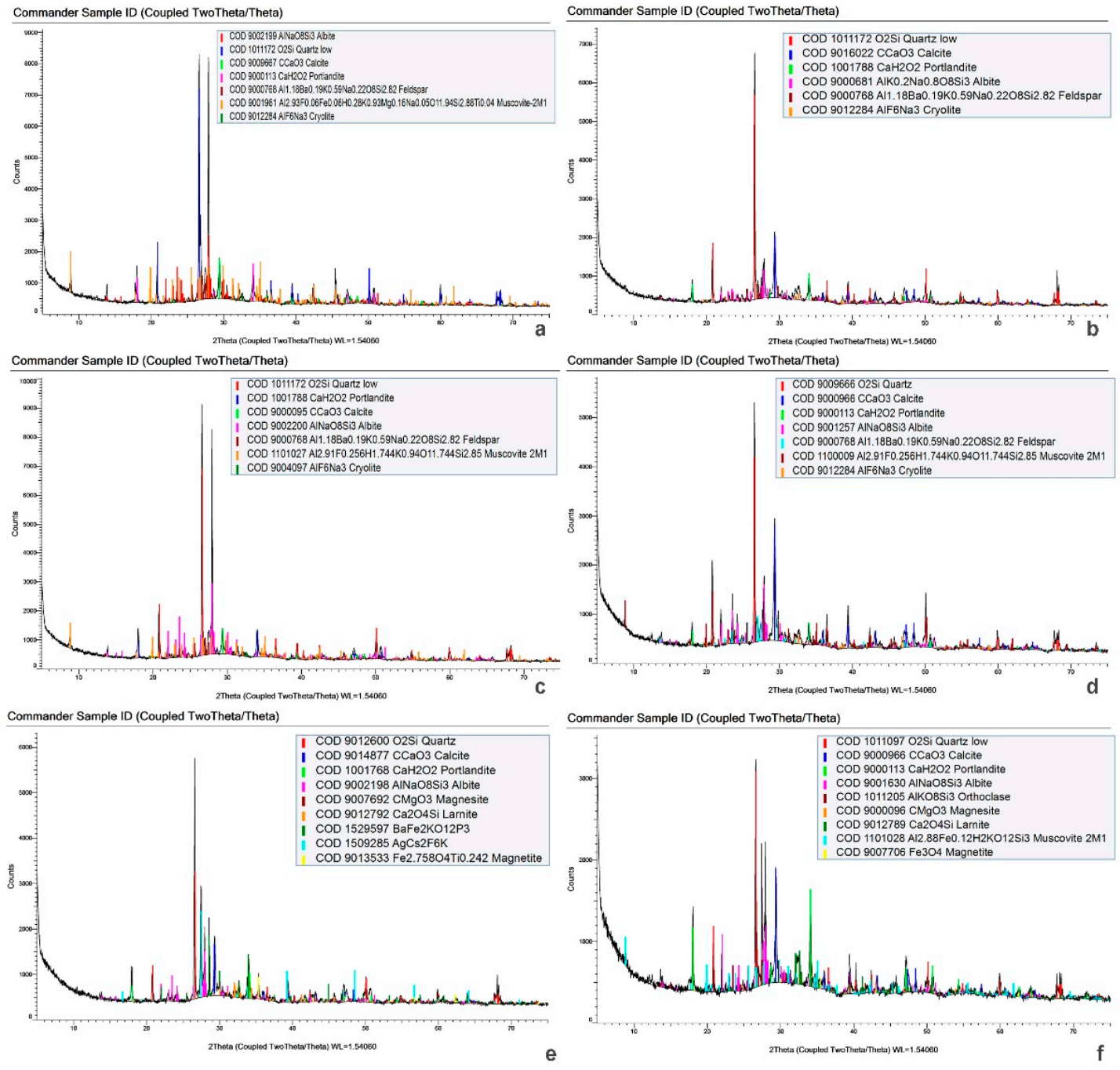

Figure 10. X-Ray diffractograms of compositions A1, A2, and B1 at ambient temperature and after exposure at $400{ }^{\circ} \mathrm{C}$. (a). A1 at ambient temperature; (b) A1 at $400{ }^{\circ} \mathrm{C}$; (c) A2 at ambient temperature; (d) A2 at $400{ }^{\circ} \mathrm{C}$; (e) B1 at ambient temperature; (f) $\mathrm{B} 1$ at $400^{\circ} \mathrm{C}$. 


\section{Conclusions}

The use of industrial byproducts, such as HCFA, LFS, and EAF, apart from the environmental benefits and relatively low cost they may offer, could contribute to the development of fire-resistant products. According to the results of the present study, the substitution of $20 \% w / w$ of OPC with HCFA and LFS, as well as of $50 \% w / w$ of natural aggregates by LFS slag, may benefit the performance of mortars exposed at extreme temperatures, as following:

- HCFA slightly increased the water demand, whereas LFS and EAF reduced it. Shrinkage deformations were lessened by HCFA and EAF slag aggregates and were induced by LFS, while porosity was increased by HCFA and LFS. It was decreased by EAF, leading to a higher apparent specific gravity and strength enhancement, around $25 \%$ for flexural and $50 \%$ for compressive strength. HCFA and LFS showed a lower strength development rate, compared to the reference mortar, attaining almost the same final values.

- After heating, HCFA addition, seemed to maintain the color hue, as well as the structural integrity of the matrix, showing the best performance among all compositions. On the other hand, slag aggregates decreased porosity, absorption, and apparent specific gravity changes, maintaining the initial values.

- Mechanical characteristics were significantly influenced by the temperature rise, with HCFA to present the lower dynamic modulus of elasticity changes and slag aggregates to maintain values in a better level. Flexural and compressive strength showed an increase at $200{ }^{\circ} \mathrm{C}$ (up to $45 \%$ ), remained in the initial level at $400{ }^{\circ} \mathrm{C}$, and were afterwards decreased. Up to $600{ }^{\circ} \mathrm{C}$, steel slag aggregates, as well as HCFA enhanced strength (around 10-25\%).

- Microstructure during heating seemed to be enhanced by slag aggregates at all temperatures and especially up to $600{ }^{\circ} \mathrm{C}$.

Generally, HCFA and LFS slag aggregates enhanced the overall performance of mortars, exposed at elevated temperatures, while LFS seemed to be beneficial only with the slag aggregates' presence. Their positive impact was mostly documented up to $600{ }^{\circ} \mathrm{C}$, after which severe physico-chemical actions imposed extreme strength and stability loss. This temperature limit is therefore crucial for the structural integrity of materials, taking into account the fire scenario and their individual characteristics.

Author Contributions: Conceptualization, V.P. and E.K.A.; methodology, V.P. and E.K.A.; software, V.P.; validation, V.P. and E.K.A.; formal analysis, V.P.; investigation, V.P.; resources, V.P. and E.K.A.; data curation, V.P.; writing-Original draft preparation, V.P.; writing-Review and editing, V.P. and E.K.A.; visualization, V.P.; supervision, V.P. and E.K.A. All authors have read and agreed to the published version of the manuscript.

Funding: This research received no external funding.

Institutional Review Board Statement: Not applicable.

Informed Consent Statement: Not applicable.

Data Availability Statement: Not applicable.

Conflicts of Interest: The authors declare no conflict of interest.

\section{References}

1. Adesina, A.D. Concrete Sustainability Issues. In Proceedings of the Cement and Concrete Science Conference, Coventry University, London, UK, 10-11 September 2018; pp. 24-26, ISBN 978-1-84600-088-1.

2. Giergiczny, Z. Fly ash and slag. Cem. Concr. Res. 2019, 124, 105826. [CrossRef]

3. Rivera, R.A.; Sanjuán, M.A.D.A. Granulated Blast-Furnace Slag and Coal Fly Ash. Ternary Portland Cements Optimization. Sustainability 2020, 12, 5783. [CrossRef]

4. Ortega, J.M.; Tremiño, R.M.; Sánchez, I.; Climent, M.A. Effects of Environment in the Microstructure and Properties of Sustainable Mortars with Fly Ash and Slag after a 5-Year Exposure Period. Sustainability 2018, 10, 663. [CrossRef]

5. Siddique, R. Utilization of industrial byproducts in concrete. Procedia Eng. 2014, 95, 335-347. [CrossRef] 
6. Corinaldesi, V.; Moriconi, G. The role of industrial byproducts in self-compacting concrete. Constr. Build. Mater. 2011, 25, 3181-3186. [CrossRef]

7. Etxeberria, M.; Pacheco, C.; Meneses, J.M.; Berridi, I. Properties of concrete using metallurgical industrial byproducts as aggregates. Constr. Build. Mater. 2010, 24, 1594-1600. [CrossRef]

8. Li, G.; Zhao, X. Properties of concrete incorporating fly ash and ground granulated blast-furnace slag. Cem. Concr. Compos. 2003, 25, 293-299. [CrossRef]

9. Dziuk, D.; Giergiczny, Z.; Garbacik, A. Calcareous fly ash as a main constituent of common cements. Roads Bridges-Drog. I Mosty 2014, 12, 57-69.

10. Setién, J.; Hernández, D.; González, J.J. Characterization of ladle furnace basic slag for use as a construction material. Constr. Build. Mater. 2009, 23, 1788-1794. [CrossRef]

11. Faleschini, F.; Pellegrino, C. Experimental behavior of reinforced concrete beams with electric arc furnace slag as recycled aggregate. ACI Mater. J. 2013, 110, 197-206.

12. Feuerborn, H.J. Coal ash utilisation over the world and in Europe. In Proceedings of the Workshop on environmental and health aspects of coal ash utilization, Tel-Aviv, Israel, 23-24 November 2005; Volume 5.

13. Shi, C. Steel slag-its production, processing, characteristics, and cementitious properties. J. Mater. Civ. Eng. 2004, 16, 230-236. [CrossRef]

14. Feldman, R.F.; Sereda, P.J. A model for hydrated Portland cement paste as deduced from sorption-length change and mechanical properties. Mater. Struct. 1968, 1, 509-519. [CrossRef]

15. Xu, Y.; Wong, Y.L.; Poon, C.S.; Anson, M. Impact of high temperature on PFA concrete. Cem. Concr. Res. 2001, 31, 1065-1073. [CrossRef]

16. Khaliq, W.; Kodur, V. High temperature mechanical properties of high strength fly ash concrete with and without fibers. ACI Mater. J. 2012, 109, 665-674.

17. Horszczaruk, E.; Sikora, P.; Cendrowski, K.; Mijowska, E. The effect of elevated temperature on the properties of cement mortars containing nanosilica and heavyweight aggregates. Constr. Build. Mater. 2017, 137, 420-431. [CrossRef]

18. Irshidat, M.R.; Al-Saleh, M.H. Thermal performance and fire resistance of nanoclay modified cementitious materials. Constr. Build. Mater. 2018, 159, 213-219. [CrossRef]

19. Pachta, V.; Triantafyllaki, S.; Stefanidou, M. Performance of lime-based mortars at elevated temperatures. Constr. Build. Mater. 2018, 189, 576-584. [CrossRef]

20. Fu, Y.F.; Wong, Y.L.; Poon, C.S.; Tang, C.A.; Lin, P. Experimental study of micro/macro crack development and stress-strain relations of cement-based composite materials at elevated temperatures. Cem. Concr. Res. 2004, 34, 789-797. [CrossRef]

21. Pachta, V.; Tsardaka, E.C.; Stefanidou, M. The role of flame retardants in cement mortars exposed at elevated temperatures. Constr. Build. Mater. 2021, 273, 122029. [CrossRef]

22. Short, N.R.; Purkiss, J.A.; Guise, S.E. Assessment of fire damaged concrete using color image analysis. Constr. Build. Mater. 2001, 15, 9-15. [CrossRef]

23. Ingham, J.P. Application of petrographic examination techniques to the assessment of fire-damaged concrete and masonry structures. Mater. Charact. 2009, 60, 700-709. [CrossRef]

24. Alani, S.; Hassan, M.S.; Jaber, A.A.; Ali, I.M. Effects of elevated temperatures on strength and microstructure of mortar containing nano-calcined montmorillonite clay. Constr. Build. Mater. 2020, 263, 120895. [CrossRef]

25. Poon, C.S.; Azhar, S.; Anson, M.; Wong, Y.L. Comparison of the strength and durability performance of normal- and high-strength pozzolanic concretes at elevated temperatures. Cem. Concr. Res. 2001, 31, 1291-1300. [CrossRef]

26. Netinger-Grubeša, I.; Rukavina, M.J.; Mladenovič, A. Impact of High Temperature on Residual Properties of Concrete with Steel Slag Aggregate. J. Mater. Civ. Eng. ASCE 2016, 28, 04016013. [CrossRef]

27. Duran-Herrera, A.; De-León-Esquivel, J.; Bentz, D.P.; Valdez-Tamez, P. Self-compacting concretes using fly ash and fine limestone powder: Shrinkage and surface electrical resistivity of equivalent mortars. Constr. Build. Mater. 2019, 199, 50-62. [CrossRef]

28. Ameri, F.; Shoaei, P.; Zahedi, M.; Karimzadeh, M.; Musaeei, H.R.; Cheah, C.B. Physico-mechanical properties and micromorphology of AAS mortars containing copper slag as fine aggregate at elevated temperature. J. Build. Eng. 2021, 39 , 102289. [CrossRef]

29. Rais, M.S.; Shariq, M.; Masood, A.; Umar, A.; Alam, M.M. An experimental and analytical investigation into age-dependent strength of fly ash mortar at elevated temperature. Constr. Build. Mater. 2019, 222, 300-311. [CrossRef]

30. Papachristoforou, M.; Anastasiou, E.K.; Papayianni, I. Durability of steel fiber reinforced concrete with coarse steel slag aggregates including performance at elevated temperatures. Constr. Build. Mater. 2020, 262, 120569. [CrossRef]

31. Anastasiou, E.K. Effect of High Calcium Fly Ash, Ladle Furnace Slag, and Limestone Filler on Packing Density, Consistency, and Strength of Cement Pastes. Materials 2021, 14, 301. [CrossRef]

32. Nasser, K.W.; Marzouk, H.M. Properties of mass concrete containing fly ash at high temperatures. ACI J. 1979, 76, 537-551.

33. Ma, Q.; Du, H.; Zhou, X.; He, K.; Lin, Z.; Yan, F.; Huang, L.; Guo, R. Performance of copper slag contained mortars after exposure to elevated temperatures. Constr. Build. Mater. 2018, 172, 378-386. [CrossRef]

34. ASTM C109/C109M-13 Standard Test Method for Compressive Strength of Hydraulic Cement Mortars (Using 2-in. or [50-mm] Cube Specimens); ASTM International: West Consohocken, PA, USA, 2013. 
35. EN 196-1. Methods of Testing Cement-Part 1: Determination of Strength; CEN—European Committee for Standardization: Brussels, Belgium, 2015.

36. ASTM C1585-13. Standard Test Method for Measurement of Rate of Absorption of Water by Hydraulic-Cement Concretes; ASTM International: West Consohocken, PA, USA, 2013.

37. ASTM C348-14. Standard Test Method for Flexural Strength of Hydraulic-Cement Mortars; ASTM International: West Consohocken, PA, USA, 2014.

38. ASTM C349-15. Standard Test Method for Compressive Strength of Hydraulic-Cement Mortars (Using Portions of Prisms Broken in Flexure); ASTM International: West Consohocken, PA, USA, 2015.

39. RILEM TC 200-HTC. Recommendation of RILEM TC 200-HTC: Mechanical concrete properties at high temperatures-modelling and applications. Part 2: Stress-strain relation. Mater. Struct. 2007, 40, 855-864. [CrossRef]

40. Sedaghatdoost, A.; Behfarnia, K.; Bayati, M.; sadegh Vaezi, M. Influence of recycled concrete aggregates on alkali-activated slag mortar exposed to elevated temperatures. J. Build. Eng. 2019, 26, 100871. [CrossRef]

41. Papayianni, I.; Anastasiou, E. Effect of granulometry on cementitious properties of ladle furnace slag. Cem. Concr. Compos. 2012, 34, 400-407. [CrossRef]

42. Gao, Y.; Hu, C.; Zhang, Y.; Li, Z.; Pan, J. Investigation on microstructure and microstructural elastic properties of mortar incorporating fly ash. Cem. Concr. Compos. 2018, 86, 315-321. [CrossRef]

43. Manso, J.M.; Polanco, J.A.; Losanez, M.; Gonzalez, J.J. Durability of concrete made with EAF slag as aggregate. Cem. Concr. Compos. 2006, 28, 528-534. [CrossRef]

44. Pellegrino, C.; Gaddo, V. Mechanical and durability characteristics of concrete containing EAF slag as aggregate. Cem. Concr. Compos. 2009, 31, 663-671. [CrossRef]

45. Rashad, A.M. An investigation of high-volume fly ash concrete blended with slag subjected to elevated temperatures. J. Clean Prod. 2015, 93, 47-55. [CrossRef]

46. Janotka, I.; Nurnbergerova, T. Effect of temperature on structural quality of the cement paste and high-strength concrete with silica fume. Nucl. Eng. Des. 2005, 235, 2019-2032. [CrossRef]

47. Patnaik, B.; Bhojaraju, C.; Mousavi, S.S. Experimental study on residual properties of thermally damaged steel fiber-reinforced concrete containing copper slag as fine aggregate. J. Mater. Cycles Waste Manag. 2020, 3, 1-15. [CrossRef]

48. Xiao, J.; Xie, M.; Zhang, C.H. Residual compressive behaviour of pre-heated high-performance concrete with blast-furnace-slag. Fire Saf. J. 2006, 41, 91-98. [CrossRef]

49. Chung, H.W.; Law, K.S. Assessing fire damage of concrete by the ultrasonic pulse technique. Cem. Concr. Aggreg. 1985, 7, 84-88.

50. Phan, L.T.; Carinoz, N.J. Review of Mechanical Properties of HSC at Elevated Temperature. J. Mater. Civ. Eng. 1998, 10, 58-65. [CrossRef] 